\title{
Attenuated Bacteria Vaccine
}

National Cancer Institute

\section{Source}

National Cancer Institute. Attenuated Bacteria Vaccine. NCI Thesaurus. Code C62761.

Any vaccine created by reducing the virulence of bacteria but still keeping the bacteria viable (live). In the production of an attenuated vaccine, the infectious agent is altered so that it becomes harmless or less virulent. This is in contrast to those vaccines produced by "killing" the pathogen (inactivated vaccine). 